\title{
Spontaneous Splenic Rupture: A Rare Complication of Acute Pancreatitis in a Patient with Crohn's Disease
}

\author{
Ghulam Mujtaba Joseph Josmi Mukul Arya Sury Anand \\ Department of Gastroenterology and Hepatology, The Brooklyn Hospital Center, \\ Brooklyn, N.Y., USA
}

\section{Key Words}

Splenic rupture - Acute pancreatitis · Crohn's disease

\begin{abstract}
Crohn's disease (CD) is an idiopathic inflammatory bowel disease which can involve any part of the gastrointestinal tract. It frequently involves the ileum, colon and the anorectum. Although rare, acute pancreatitis as a complication of $C D$ involving the duodenum has been described in the literature. We describe a 37-year-old male with CD presenting with acute pancreatitis and spontaneous splenic rupture. The potential mechanisms associated with acute pancreatitis along with spontaneous rupture of the spleen in this patient population and its treatment will be discussed. Common complaints such as upper abdominal pain in a patient with CD should undergo workup to exclude less commonly involved sites such as the pancreas and spleen. Close monitoring in the critical care setting is recommended in carefully selected and hemodynamically stable patients with splenic rupture. Surgical treatment is considered as the standard of care in hemodynamically unstable patients.
\end{abstract}

\section{Introduction}

Spontaneous rupture of the spleen is a rare disorder and has been reported to occur in hematological, neoplastic and infectious processes involving the spleen or as a complication of pancreatitis. Spontaneous splenic rupture was first described in 1922 by Friesleben [1] and is associated with a high mortality, usually due to failure or delay in making the diagnosis [2]. We report a case of spontaneous splenic rupture in a patient with poorly controlled Crohn's disease (CD) presenting with acute pancreatitis. 


\begin{tabular}{|c|c|c|c|}
\hline $\begin{array}{r}\text { Case Reports in } \\
\text { castroenterolowy }\end{array}$ & $\begin{array}{l}\text { Case Rep Gastroenterol 2011;5:179-182 } \\
\text { DOI: } 10.1159 / 000327215\end{array}$ & $\begin{array}{l}\text { Published online: } \\
\text { April 13, } 2011\end{array}$ & \begin{tabular}{|l} 
@ 2011 S. Karger AG, Basel \\
ISSN $1662-0631$ \\
www.karger.com/crg
\end{tabular} \\
\hline
\end{tabular}

\section{Case Report}

A 37-year-old male with known history of CD involving primarily the colon was admitted with a complaint of upper abdominal pain for the last 2 weeks. He denied nausea, emesis, hematemesis, hematochezia or abdominal trauma. His home medications were pantoprazole, hydrocortisone enema, and ferrous sulphate. He denied alcohol, tobacco and illicit drug use. The rest of his medical history was unremarkable. Examination revealed an afebrile hemodynamically stable male with left upper quadrant tenderness to deep palpation, without guarding, mass or rebound. Initial laboratory investigations revealed a white cell count of 17,900/dl (reference range 4,000-11,000/dl) and a hemoglobin of $7.9 \mathrm{~g} / \mathrm{dl}$ (reference range 12-16 g/dl). Serum amylase was $202 \mathrm{IU} / \mathrm{l}$ (reference range 45-200 IU/l) and lipase was 177 IU/l (reference range 35-95 IU/l). The remainder of the laboratory data was within normal limits. Ultrasonographic examination of the abdomen did not show gallstones, biliary sludge or dilated common bile duct. Contrast-enhanced computed tomography scan of abdomen (fig. 1, fig. 2, fig. 3) showed a moderate hemoperitoneum from spontaneous splenic rupture, splenic vein thrombosis, markedly edematous pancreatic head, body and tail, peripancreatic inflammatory changes and colon wall thickening. Given acute pancreatitis with splenic rupture, the patient was admitted to the intensive care unit for optimization of fluid status and close monitoring. He received two units of packed red blood cells with a corresponding rise in hemoglobin to $10.1 \mathrm{~g} / \mathrm{dl}$. Side-viewing duodenoscopy showed a normal-looking ampulla and cholangiography did not reveal stones in the bile duct. The patient was treated conservatively, with close monitoring of hematocrit, for ruptured spleen as it was well localized. Hydrocortisone enema was continued to treat his CD.

\section{Discussion}

A true 'spontaneous' rupture of the spleen has been described by Orloff and Peskin in 1958 as it occurs in the absence of trauma in the spleen and the affected patient should not have any disease that could involve the spleen [3]. A recent literature review by Renzulli et al. found neoplasia as the most frequently reported pathology in atraumatic splenic rupture followed by infectious, inflammatory and noninfectious causes [4].

Spontaneous splenic rupture has been reported with acute pancreatitis, in the setting of splenic vein thrombosis, perisplenic adhesions, and acute inflammation of entopic intrasplenic pancreatic tissue [5-8]. Acute pancreatitis has been associated with CD involving the duodenum, secondary to mucosal disruption of the ampulla with resultant reflux of duodenal contents into the pancreatic ducts $[9,10]$. Our patient had CD involving only the distal colon established by clinical, radiographic, endoscopic, and pathologic criteria. There were no fistulas between the gastrointestinal tract, spleen and pancreas radiographically. Although the pathophysiology of this occurrence has not been described, we believe that the underlying poorly controlled CD was a major contributor to the initiation of inflammation in the pancreas. This resulted in the subsequent splenic vein thrombosis and eventual splenic rupture. Patients with inflammatory bowel disease presenting with nonspecific abdominal pain should undergo workup to exclude such rare complications. Timely and accurate diagnosis of splenic and pancreatic involvement may improve patient outcome.

The choice of therapy is determined by the hemodynamic stability of the patient, the degree of hemoperitoneum, the amount of blood products needed, and the extent of the splenic injury as assessed by the AAST classification [11,12]. A recent report by Meguid et al. has mentioned successful conservative management in 5 of 9 patients admitted with blunt splenic injury and concomitant infectious mononucleosis [13]. 


\begin{tabular}{r|l|l|l} 
Case Reports in & $\begin{array}{l}\text { Case Rep Gastroenterol 2011;5:179-182 } \\
\text { DOI: 10.1159/000327215 }\end{array}$ & $\begin{array}{l}\text { Published online: } \\
\text { April 13, 2011 }\end{array}$ & $\begin{array}{l}\text { O 2011 S. Karger AG, Basel } \\
\text { ISSN 1662-0631 } \\
\text { www.karger.com/crg }\end{array}$ \\
\hline
\end{tabular}

In conclusion, nonsurgical management with close clinical and sonographic monitoring is recommended in a group of patients who are hemodynamically stable [14]. Surgical intervention is recommended in hemodynamically unstable patients who have peritoneal signs, radiographic findings or positive diagnostic peritoneal lavage [15].

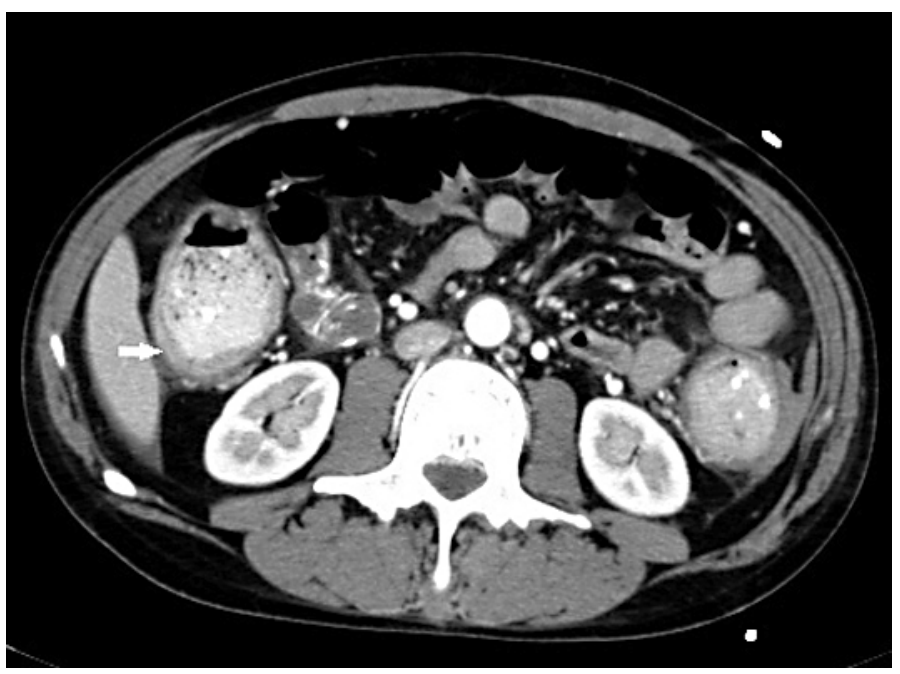

Fig. 1. Colon wall thickening (arrow).

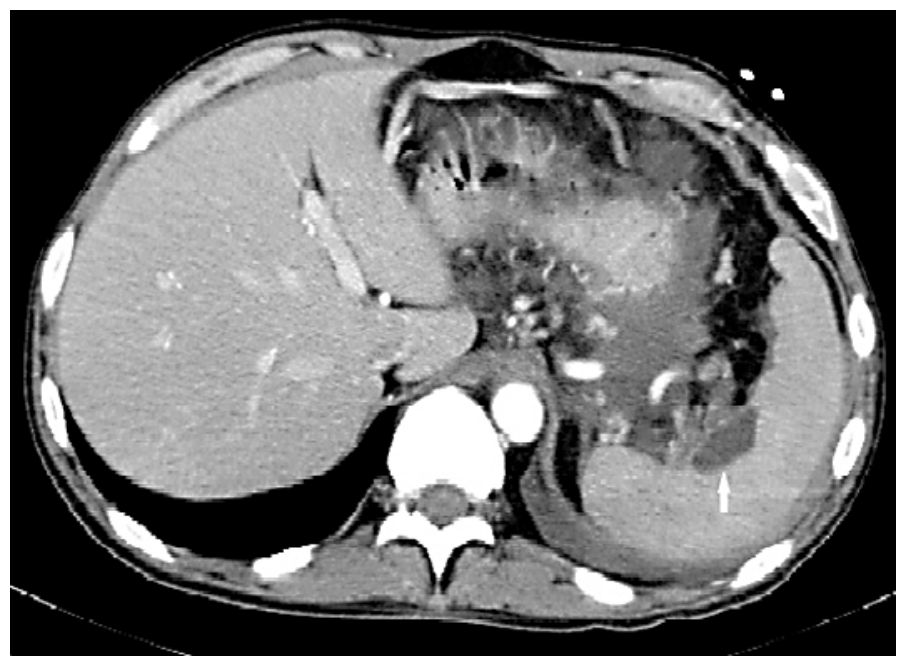

Fig. 2. Splenic hemorrhage (arrow). 


\begin{tabular}{r|l|l|l} 
Case Reports in & $\begin{array}{l}\text { Case Rep Gastroenterol 2011;5:179-182 } \\
\text { DOI: 10.1159/000327215 }\end{array}$ & $\begin{array}{l}\text { Published online: } \\
\text { April 13, 2011 }\end{array}$ & $\begin{array}{l}\text { (2011 S. Karger AG, Basel } \\
\text { ISSN 1662-0631 } \\
\text { www.karger.com/crg }\end{array}$ \\
\hline
\end{tabular}

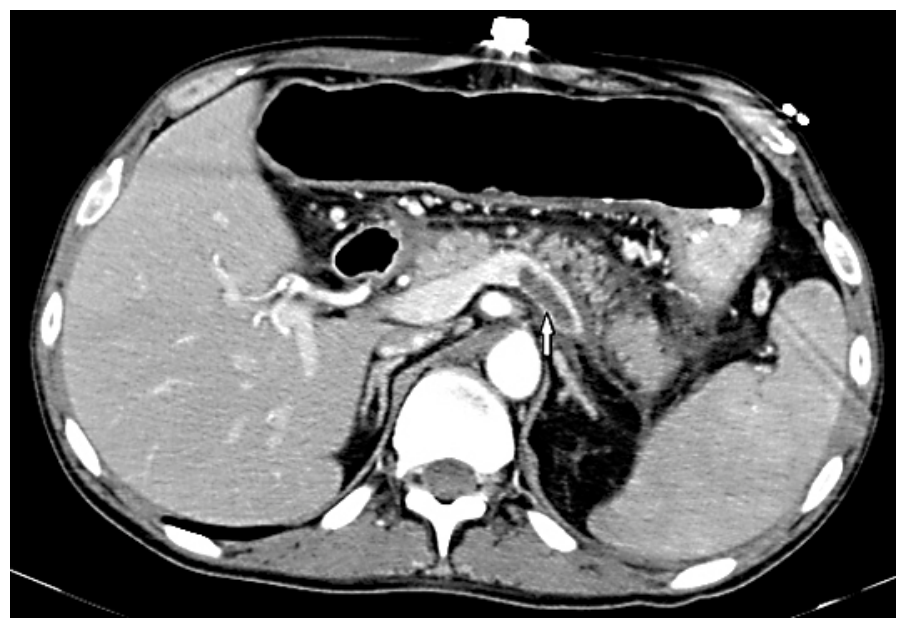

Fig. 3. Splenic vein thrombosis (arrow).

\section{References}

1 Friesleben M: Ein durch Splenektomie geheilter seltener Fall von Spontanruptur der Milz. Dtsch Z Chir 1922;173:45-64.

-2 McMahon MJ, Lintott JD, Mair WS, et al: Occult rupture of the spleen. Br J Surg 1977;64:641-643.

-3 Orloff MJ, Peskin GW: Spontaneous rupture of the normal spleen, a surgical enigma. Int Abstr Surg 1958;106:1-11.

- Renzulli P, Hostettler A, Schoepfer AM, et al: Systematic review of atraumatic splenic rupture. Br J Surg 2009;96:1114-1121.

5 Mallory TB, Castleman B, Parris EE: Case records of the Massachusetts General Hospital Weekly Clinicopathological Exercises. N Eng J Med 1945;233:443-447.

6 LaBree RH, Fuller J, Boman PG: Spontaneous rupture of the spleen after acute pancreatits. JAMA 1960;172: 816-817.

7 Donckier V, Rypens F, Van de Stadt J: Unusual splenic complication of acute pancreatitis. J Clin Gastroenterol 1992;15:245-247.

8 Fishman EK, Soyer P, Bliss DF, et al: Splenic involvement in pancreatitis: spectrum of CT findings. AJR Am J Roentgenol 1995;164:631-635.

-9 Barthelemy CR: Crohn's disease of the duodenum with spontaneous reflux into the pancreatic duct. Gastrointest Radiol 1983;8:319-320.

10 Legge DA, Hoffman HN II, Carlson HC: Pancreatitis as a complication of regional enteritis of the duodenum. Gastroenterology 1971;61:834-837.

11 Moore EE, Cogbill TH, Jurkovich GJ, et al: Organ injury scaling: spleen and liver (1994 revision). J Trauma 1995;38:323-324.

12 Peitzman AB, Heil B, Rivera L, et al: Blunt splenic injury in adults: multi-institutional study of the Eastern Association for the Surgery of Trauma. J Trauma 2000;49:177-189.

13 Meguid AA, Ivascu FA, Bair HA, et al: Management of blunt splenic injury in patients with concurrent infectious mononucleosis. Am Surg 2004;70:801-804.

14 Guth AA, Pachter HL, Jacobowitz GR: Rupture of the pathologic spleen: is there a role for nonoperative therapy? J Trauma 1996;412:214-218.

15 Hadary A, Dashkovsky I, Rapaport A, et al: Non-traumatic rupture of spleen: can splenectomy be applied selectively? Isr Med Assoc J 2008;10:889-891. 